\title{
Vitamin D supplementation on anemia markers and the impact on PTH in patients
}

\section{with chronic kidney disease}

\author{
Suplementação de vitamina D sobre os marcadores de anemia e o impacto sobre o PTH em \\ pacientes com doença renal crônica \\ La suplementación con vitamina D sobre los marcadores de anemia y el impacto sobre la PTH en \\ pacientes con enfermedad renal crónica
}

Received: 06/30/2021 | Reviewed: 07/06/2021 | Accept: 07/26/2021 | Published: 08/02/2021

Letícya Thaís Mendes Viana

ORCID: https://orcid.org/0000-0002-9707-0931

Universidade Federal do Piauí, Brazil

E-mail: leticyathais16@hotmail.com

Larissa Lages Rodrigues

ORCID: https://orcid.org/0000-0002-1702-1428

Universidade Federal do Piauí, Brazil

E-mail: larisalages@gmail.com

Jurandy do Nascimento Silva

ORCID: https://orcid.org/0000-0002-4755-5121

Instituto Federal do Piauí, Brazil

E-mail: jurandy@ifpi.edu.br

Maria Márcia Dantas de Sousa

ORCID: https://orcid.org/0000-0003-4681-1696 Instituto Federal do Piauí, Brazil

E-mail: mariamarciadantas@ hotmail.com Fhanuel Silva Andrade

ORCID: https://orcid.org/0000-0001-7053-9456

Instituto Federal do Piauí, Brazil

E-mail: fhanuelfsa@gmail.com

Betânia de Jesus e Silva de Almendra Freitas

ORCID: https://orcid.org/0000-0002-7797-735X

Universidade Federal do Piauí, Brazil

E-mail: betaniafreitas2004@yahoo.com.br

\begin{abstract}
Chronic Kidney Disease (CKD) is an injury that causes progressive impairment of exocrine and endocrine renal functions. A very common complication is anemia, caused by reduced erythropoietin production, iron deficiency and inflammation. Evidence demonstrates that vitamin D has effects on anemia of inflammation, through the increase in erythrocytes and decrease in pro-inflammatory cytokines. This study aims to review the effects of vitamin D supplementation on $25(\mathrm{OH}) \mathrm{D}_{2}$ concentrations, on anemia markers and on PTH levels. This is an integrative review carried out through the search and selection of original publications, in english and portuguese, indexed in PubMed, Web of Science and Science Direct databases belonging to the 2010-2020 range. The results pointed to $25(\mathrm{OH}) \mathrm{D}_{2}$ concentrations compatible with normality after vitamin D supplementation. In five studies, there was no change in hemoglobin and PTH levels, and in four studies there was a reduction in the dose of EPO or erythroid stimulating agent, attributing such effect on the role of calcitriol as a substrate for bone marrow erythropoietic cells. The study concluded that vitamin D supplementation had beneficial effects for correction of $25(\mathrm{OH}) \mathrm{D}_{2}$ deficiency, however, it reinforces the controversy about the behavior of vitamin D on the improvement of anemia markers and PTH levels in patients with DRC. Therefore, it is suggested that the beneficial effect of vitamin D on anemia in renal patients may be independent of PTH suppression.
\end{abstract}

Keywords: Vitamin D supplementation; Cholecalciferol; Erythropoietin; Hemoglobin; Anemia; Chronic kidney disease.

\section{Resumo}

A Doença Renal Crônica (DRC) é uma lesão que ocasiona comprometimento progressivo das funções renais exócrinas e endócrinas. Uma complicação muito comum é a anemia, causada pela redução na produção de eritropoetina, deficiência de ferro e inflamação. Evidências demonstram que a vitamina D apresenta efeitos sobre a anemia da inflamação, por meio do aumento de eritrócitos e diminuição de citocinas pró-inflamatórias. Esse estudo objetiva revisar os efeitos da suplementação de vitamina $\mathrm{D}$ sobre as concentrações de $25(\mathrm{OH}) \mathrm{D}_{2}$, nos marcadores de 
anemia e nos níveis de PTH. Trata-se de uma revisão integrativa realizada por meio da busca e seleção de publicações originais, nos idiomas inglês e português, indexados nas bases de dados PubMed, Web of Science e Science Direct pertencentes ao intervalo de 2010-2020. Os resultados apontaram para concentrações de $25(\mathrm{OH}) \mathrm{D}_{2}$ compatíveis com normalidade após suplementação de vitamina D. Em cinco estudos prevaleceu sem modificação nos níveis de hemoglobina e PTH, e em quatro estudos houve redução da dose de EPO ou agente estimulador eritróide, atribuindo tal efeito ao papel do calcitriol como substrato para as células eritropoiéticas da medula óssea. O estudo concluiu que a suplementação de vitamina $\mathrm{D}$ apresentou efeitos benéficos para correção da deficiência de $25(\mathrm{OH}) \mathrm{D}_{2}$, no entanto, reforçam a controvérsia acerca do comportamento da vitamina $\mathrm{D}$ sobre a melhora dos marcadores de anemia e nos níveis de PTH em pacientes com DRC. Sendo assim, sugere-se que o efeito benéfico da vitamina D na anemia em pacientes renais possa ser independente da supressão do PTH.

Palavras-chave: Suplementação de vitamina D; Colecalciferol; Eritropoietina; Hemoglobina; Anemia; Doença renal crônica.

\section{Resumen}

La enfermedad renal crónica (ERC) es una lesión que causa deterioro progresivo de las funciones renales exocrinas y endocrinas. Una complicación muy común es la anemia, causada por la reducción de la producción de eritropoyetina, la deficiencia de hierro y la inflamación. La evidencia demuestra que la vitamina D tiene efectos sobre la anemia de la inflamación, a través del aumento de eritrocitos y disminución de citocinas proinflamatorias. Este estudio tiene como objetivo revisar los efectos de la suplementación con vitamina $\mathrm{D}$ en las concentraciones de $25(\mathrm{OH}) \mathrm{D}_{2}$, en los marcadores de anemia y en los niveles de PTH. Se trata de una revisión integradora realizada a través de la búsqueda y selección de publicaciones originales, en inglés y portugués, indexadas en las bases de datos PubMed, Web of Science y Science Direct pertenecientes a la gama 2010-2020. Los resultados señalaron concentraciones de $25(\mathrm{OH}) \mathrm{D}_{2}$ compatibles con la normalidad después de la suplementación con vitamina D. En cinco estudios, no hubo cambios en los niveles de hemoglobina y PTH, y en cuatro estudios hubo una reducción en la dosis de EPO o agente estimulante eritroide, atribuyendo dicho efecto al papel del calcitriol como sustrato de las células eritropoyéticas de la médula ósea. El estudio concluyó que la suplementación con vitamina D tuvo efectos beneficiosos para la corrección de la deficiencia de $25(\mathrm{OH}) \mathrm{D}_{2}$, sin embargo, refuerza la controversia sobre el comportamiento de la vitamina $\mathrm{D}$ en la mejora de los marcadores de anemia y los niveles de PTH en pacientes con DRC. Por lo tanto, se sugiere que el efecto beneficioso de la vitamina D sobre la anemia en pacientes renales puede ser independiente de la supresión de PTH.

Palabras clave: Suplementación con vitamina D; Colecalciferol; Eritropoyetina; Hemoglobina; Anemia; Enfermedad renal crónica.

\section{Introduction}

Chronic Kidney Disease (CKD) is a global health problem (Daimon et al., 2020). In recent years, with increasing longevity, there has been a trend towards an increase in the number of patients on dialysis, as attested by the Brazilian Chronic Dialysis Survey conducted in 2019, where 139.691 patients were on dialysis in the country (Neves et al., 2021).

Anemia secondary to CKD is a complication that is often not treated, which occurs early in the course of the disease and can become intractable with the decline in kidney function resulting in high morbidity, increased hospitalizations, impaired cognition and mortality (Begum \& Latunde-Dada, 2019).

The main causes of anemia are: reduced production of erythropoietin (EPO), which stimulates the production of erythrocytes (Bueno \& Frizzo, 2014; Naini et al., 2015; Oliveira et al., 2019; Agarwal, 2021), deficiency of iron, inflammation, and vitamin D axis deficiencies (Zughaier et al., 2014; Bacchetta et al., 2014; Lima, 2017; Al-shaer et al., 2020).

Attempts to improve the prevention and treatment of anemia or the use of potential therapies can help to reduce the burden of the disease (Arabi et al., 2020). Vitamin D can have a favorable impact on anemia control, particularly anemia of inflammation, by increasing erythroid progenitor proliferation and decreasing hepcidin-stimulating pro-inflammatory cytokines, thus reducing their concentrations, as well as acting directly on the hepcidin, down-regulating the transcription of messenger RNA (mRNA) of the antimicrobial peptide hepcidin (Sim et al., 2010; Smith \& Tangpricha, 2015; Naini et al., 2015; Masoud et al., 2018).

In some CKD patients with suboptimal response to EPO, vitamin D therapy leads to improvement of anemia and reduced need for the EPO dose in patients without depletion in parathyroid hormone (PTH) levels. In this theme, it was observed that 1,25-di-hidroxivitamina $\mathrm{D}\left(1,25(\mathrm{OH}) 2 \mathrm{D}_{3}\right)$, also called calcitriol directly increased the proliferation of erythroid 
precursors, by activating $1 \alpha$-hydroxylase (Madu \& Ughasoro, 2017), in addition, 1,25(OH)2 $\mathrm{D}_{3}$ has been shown to increase EPO receptor expression and synergistically stimulate proliferation along with EPO (Patel et al., 2010; Riccio et al., 2015; Sonkar et al., 2018).

Considering that vitamin D supplementation can have a favorable impact on the control of anemia, particularly in anemia of inflammation and/or reduction in EPO requirements, this study aimed to review the effects of vitamin D supplementation on concentrations of $25(\mathrm{OH}) \mathrm{D}_{2}$, anemia markers (EPO, hemoglobin, ferritin and transferrin saturation) and PTH levels, considering possible ways of interaction, based on the literature.

\section{Methodology}

This is an integrative, qualitative literature review. The construction of this study followed the following steps: Elaboration of the theme, definition of eligibility criteria, characterization of the studies, analysis of results, compiled in the final table and discussion of the review's findings (Mowbray et al., 2014).

The main author (LTMV) was responsible for carrying out the search, through which original publications, in English and Portuguese, from 2010 to 2020, conducted in humans and indexed in the databases Pubmed, Web of Science and Science Direct.

In this study, the PICO (Patient, Intervention, Comparison and Outcomes) strategy was applied to define the following guiding question: "What is the effect of vitamin D supplementation on serum concentrations of $25(\mathrm{OH}) \mathrm{D}_{2}$ and profile of anemia markers in chronic renal patients?". Patients with anemia and chronic kidney disease were defined as $\mathrm{P}$ (Population and Problem); I (Intervention) oral vitamin D supplementation; C (Comparison) placebo or control groups (negative or positive); the (Outcome) effects of supplementation on the cholecalciferol profile (and isoforms) and anemia markers. For the bibliographic survey, the following keywords and their respective terms in english were considered: Suplementação de Vitamina D (Vitamin D supplementation); Colecalciferol (Cholecalciferol); Eritropoetina (Erythropoietin); Hemoglobina (Hemoglobin); Anemia (Anemia); and Doença Renal Crônica (Chronic Kidney Disease). It is noteworthy that the searches were performed using the free terms and equated with the use of boolean operators.

Eligibility criteria were defined as: original case-control, cross-sectional, cohort, longitudinal, observational studies, clinical trials, conducted in humans and with no age restrictions for the investigated population. In turn, case reports, review articles, without full access, research in experimental design in vitro, as well as studies that related to the proposed theme (Vitamin D (ergocalciferol/D2 or cholecalciferol/D3), Chronic Kidney Disease, Anemia Markers), were removed due to ineligibility.

The main information of the studies was gathered, which included: name of the authors, year of publication, country of research, type of study, sample size, age, dose and time of vitamin D supplementation (and isoforms), and the outcome observed. All of these data were exposed in table 1 of the Results.

Figure 1 illustrates the total number of articles obtained in the respective databases, based on the combination of the descriptors defined for search. It was observed that 8 articles were included for the final analysis corpus of this review. 
Figure 1. Diagram of the steps for selecting the reviewed articles.

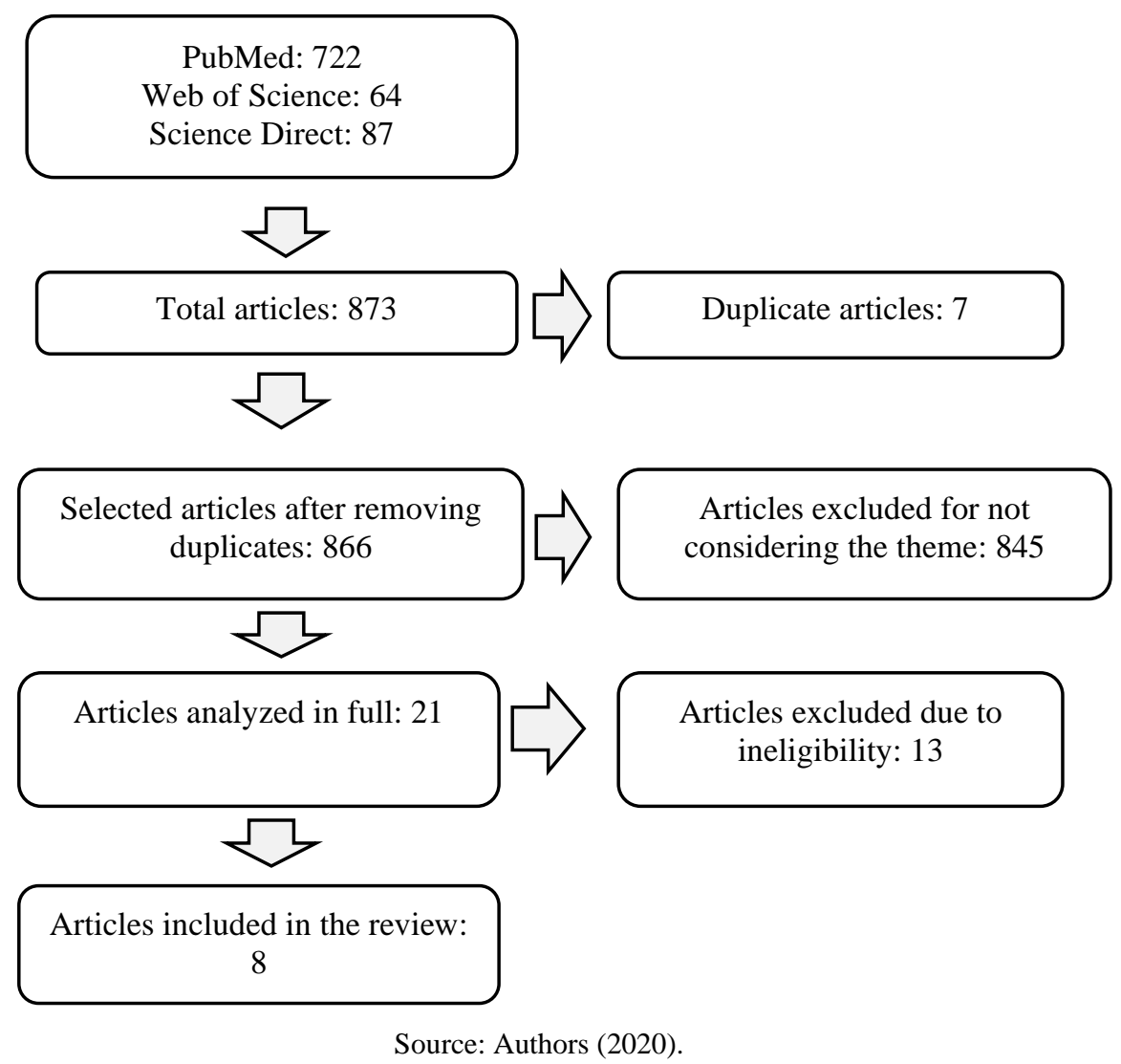

\section{Results}

A total of 873 articles were found, of which 722 were obtained from the Pubmed database, 64 from the Web of Science and 87 from Science Direct. After the process of choosing and analyzing articles, considering the inclusion and removal criteria for duplicate articles, 8 articles were selected to compose this integrative review. 
Table 1. Summary of characteristics and results observed in the intervention studies in this review.

\begin{tabular}{|c|c|c|c|c|c|}
\hline Author/Year/Country & Design & Sample (n) & Age (years) & $\begin{array}{l}\text { Dose and Time of } \\
\text { Supplementation }\end{array}$ & Outcomes \\
\hline $\begin{array}{c}\text { Matias et al., } 2010 . \\
\text { Portugal }\end{array}$ & $\begin{array}{l}\text { Prospective } \\
\text { cohort }\end{array}$ & $\begin{array}{l}\mathrm{n}=158 \\
\text { Adults }\end{array}$ & $62,8^{*}$ & $\begin{array}{l}\text { (1) }<15 \mathrm{ng} / \mathrm{mL}-50.000 \\
\text { IU/week; } \\
\text { (2) } 16-30 \mathrm{ng} / \mathrm{mL}-10.000 \\
\text { IU/week; } \\
\text { (3) }>30 \mathrm{ng} / \mathrm{mL}-2700 \text { IU three } \\
\text { times a week. } \\
\text { Duration: } 6 \text { months }\end{array}$ & $\begin{array}{l}86 \% \text { of patients achieved }\left[25(\mathrm{OH}) \mathrm{D}_{2}\right]>30 \mathrm{ng} / \mathrm{mL} \text {. } \\
\text { Darbepoetin use also decreased, with no change in } \mathrm{Hb} \\
\text { values. There was no change in ferritin levels. PTH levels } \\
\text { showed a significant decrease. }\end{array}$ \\
\hline $\begin{array}{c}\text { Kumar et al., } 2011 . \\
\text { EUA }\end{array}$ & $\begin{array}{l}\text { Prospective } \\
\text { cohort }\end{array}$ & $\begin{array}{c}\mathrm{n}=81 \\
\text { Adults }\end{array}$ & $62 *$ & $\begin{array}{l}\text { (1) } \leq 10 \mathrm{ng} / \mathrm{mL}-50.000 \mathrm{IU} \\
\text { weekly for } 1 \mathrm{month} \text {, followed } \\
\text { by } 50.000 \text { IU monthly for } 3 \\
\text { months; } \\
\text { (2) } 10-30 \mathrm{ng} / \mathrm{mL}-50.000 \mathrm{IU} \\
\text { monthly. } \\
\text { Duration: } 4 \text { months. }\end{array}$ & $\begin{array}{l}{\left[25(\mathrm{OH}) \mathrm{D}_{2}\right] \text { improved, but only } 44 \% \text { reached the target of }} \\
30 \mathrm{ng} / \mathrm{mL} \text {. The dose of EPO was reduced in } 57 \% \text { of } \\
\text { participants. There was no change in Hb levels. } \\
\text { Transferrin saturation was higher in patients with } \\
{\left[25(\mathrm{OH}) \mathrm{D}_{2}\right] \geq 30 \mathrm{ng} / \mathrm{mL} \text { and ferritin levels were higher in }} \\
\text { participants with }\left[25(\mathrm{OH}) \mathrm{D}_{2}\right]<30 \mathrm{ng} / \mathrm{mL} \text {. There was no } \\
\text { difference in PTH levels. }\end{array}$ \\
\hline $\begin{array}{c}\text { Porter et al., } 2013 . \\
\text { EUA }\end{array}$ & $\begin{array}{c}\text { Retrospective } \\
\text { cohort }\end{array}$ & $\begin{array}{l}\mathrm{n}=96 \\
\text { Adults }\end{array}$ & $\begin{array}{c}52,5 \text { e } 59,7 * \\
\text { (by group) }\end{array}$ & $\begin{array}{l}\text { 1) }<5 \mathrm{ng} / \mathrm{mL}-50.000 \text { IU } / 12 \\
\text { weeks, then } 3 \text { doses monthly; } \\
\text { (2) } 5-15 \mathrm{ng} / \mathrm{mL}-50.000 \mathrm{IU} / 4 \\
\text { weeks, then } 5 \text { doses monthly; } \\
\text { (3) } 16-30 \mathrm{ng} / \mathrm{mL}-50.000 \\
\text { IU/6 months. } \\
\text { Duration: } 11 \text { months. }\end{array}$ & $\begin{array}{l}\text { After } 6 \text { months of treatment, the case group showed an } \\
\text { increase in }\left[25(\mathrm{OH}) \mathrm{D}_{2}\right] \text {. At } 11 \text { months }\left[25(\mathrm{OH}) \mathrm{D}_{2}\right] \\
\text { reduced. There was no change in } \mathrm{Hb} \text { and PTH levels. }\end{array}$ \\
\hline $\begin{array}{l}\text { Naini et al., } 2015 . \\
\text { Irã }\end{array}$ & $\begin{array}{l}\text { Clinical trial } \\
\text { double-blind }\end{array}$ & $\begin{array}{c}\mathrm{n}=64 \\
\text { Adults }\end{array}$ & $\begin{array}{c}60 \text { e } 62 * \\
\text { (by group) }\end{array}$ & $\begin{array}{l}\text { 50.000IU/week for } 12 \text { weeks. } \\
\text { Every three weeks until each } \\
\text { patient has taken } 650.000 \mathrm{IU} \text { of } \\
\text { vitD. } \\
\text { Duration: } 4 \text { months. }\end{array}$ & $\begin{array}{l}\text { Mean [vitD] increased by } 58,04 \mathrm{ng} / \mathrm{mL} \text { in the treatment } \\
\text { group. This showed a significant decrease in the required } \\
\text { dose of EPO. There was no significant difference in } \mathrm{Hg} \\
\text { levels. }\end{array}$ \\
\hline $\begin{array}{c}\text { Miskulin et al., } 2016 . \\
\text { EUA }\end{array}$ & Clinical trial & $\begin{array}{l}\mathrm{n}=252 \\
\text { Adults }\end{array}$ & $61 *$ & $\begin{array}{l}\text { (1) }<15 \mathrm{ng} / \mathrm{mL}-50.000 \\
\text { IU/week for } 6 \text { months; } \\
\text { (2) } 16-30 \mathrm{ng} / \mathrm{ml}-50.000 \\
\text { IU/week for } 3 \text { months, then } 1\end{array}$ & $\begin{array}{l}\text { At } 6 \text { months of treatment, there was an increase in } \\
{\left[25(\mathrm{OH}) \mathrm{D}_{2}\right] \text {. The weekly dose of epoetin did not change }} \\
\text { significantly in any group. There was no difference in } \\
\text { PTH levels. }\end{array}$ \\
\hline
\end{tabular}




\begin{tabular}{|c|c|c|c|c|c|}
\hline & & & & $\begin{array}{l}\text { dose per month for } 3 \text { months. } \\
\text { Duration: } 6 \text { months }\end{array}$ & \\
\hline $\begin{array}{c}\text { Agarwal et al., } 2016 . \\
\text { EUA }\end{array}$ & Case-control & $\begin{array}{l}\mathrm{n}=186 \\
\text { Adults }\end{array}$ & $57,6^{*}$ & $\begin{array}{l}\text { (1) }<5 \mathrm{ng} / \mathrm{mL}-50.000 \mathrm{IU} / 12 \\
\text { weeks, then monthly; } \\
\text { (2) } 5-15 \mathrm{ng} / \mathrm{mL}-50.000 \mathrm{IU} / 4 \\
\text { weeks, then monthly; } \\
\text { (3): } 16-30 \mathrm{ng} / \mathrm{mL}-50.000 \\
\text { IU/month. } \\
\text { Duration: } 12 \text { months. }\end{array}$ & $\begin{array}{l}50 \% \text { of the sample reached vitD sufficiency at } 12 \text { months. } \\
\text { There was no treatment effect on EPO dose reduction. } \\
\text { Ferritin and transferrin saturation levels decreased in the } \\
\text { case group during } 12 \text { months. There was no difference in } \\
\text { PTH levels. }\end{array}$ \\
\hline $\begin{array}{c}\text { Nand \& Mittal, } 2017 . \\
\text { Índia }\end{array}$ & Case-control & $\begin{array}{l}\mathrm{n}=50 \\
\text { Adults }\end{array}$ & $* *$ & $\begin{array}{l}\text { (1) }<30 \mathrm{ng} / \mathrm{mL}-60.000 \\
\text { IU/week; } \\
\text { (2) }>30 \mathrm{ng} / \mathrm{mL}-\text { control group. } \\
\text { Duration: } 4 \text { months }\end{array}$ & $\begin{array}{l}\text { At the end of four months of supplementation, there was a } \\
\text { significant increase in } \mathrm{Hb} \text { and a significant decrease in } \\
\text { EPO, ferritin and PTH. }\end{array}$ \\
\hline $\begin{array}{l}\text { Obi et al., } 2020 . \\
\text { Japão }\end{array}$ & Clinical trial & $\begin{array}{l}\mathrm{n}=88 \\
\text { Adults }\end{array}$ & $67 *$ & $\begin{array}{l}\text { (1) Cholecalciferol - } 3.000 \mathrm{IU} \\
\text { 3x/week; } \\
\text { (2) Cholecalciferol }-9.000 \\
\text { IU/month. } \\
\text { Duration: } 6 \text { months }\end{array}$ & $\begin{array}{l}\text { Administration three times a week and once a month } \\
\text { increased }\left[25(\mathrm{OH}) \mathrm{D}_{2}\right] \text { and }\left[1,25(\mathrm{OH}) 2 \mathrm{D}_{3}\right] \text {. There was no } \\
\text { change in the weekly dose of darbepoetin in the } \\
\text { cholecalciferol-treated groups at } 6 \text { months of treatment. } \\
\text { There were no differences between groups for Hb, ferritin, } \\
\text { transferrin saturation and PTH. }\end{array}$ \\
\hline
\end{tabular}

Legend: * Average age values; ** uninformed; [ ] concentrations; USA = United States of America; vitD = vitamin $\mathrm{D} ; 25(\mathrm{OH}) \mathrm{D}_{2}=25$-hydroxyvitamin $\mathrm{D} ; 1,25(\mathrm{OH}) 2 \mathrm{D}_{3}=1,25$-dihydroxyvitamin $\mathrm{D} ; \mathrm{UI}=$ international unit; $\mathrm{EPO}=$ erythropoietin; $\mathrm{PTH}=$ parathyroid hormone; $\mathrm{Hg}=$ hemoglobin.

Source: Authors (2020). 
The table above compiles the main information obtained from the selected articles and comprised in the range from 2010 to 2020. Based on the above, it was observed that the selected studies were carried out in different countries (Portugal, United States, Iran, India and Japan), and presented a sample size that varied from 64 to 256 participants. As for the research design, we obtained: prospective and retrospective cohort, case-control and clinical trials. Although the study designs are different, they were all based on interventions with vitamin D supplementation.

Matias et al. (2010), Kumar et al. (2011), Naini et al. (2015), Agarwal et al. (2016) and Obi et al. (2020) observed an increase in the concentration of $25(\mathrm{OH}) \mathrm{D}_{2}$ with vitamin $\mathrm{D}$ supplementation. Porter et al. (2013) found an oscillation in the concentration of $25(\mathrm{OH}) \mathrm{D}_{2}$; at 6 months of treatment there was a significant increase, and 11 months after the $25(\mathrm{OH}) \mathrm{D}_{2}$ concentration decreased, with only $37 \%$ of the case group maintaining an adequate level. In turn, in the study by Miskulin et al. (2016), the concentration of $25(\mathrm{OH}) \mathrm{D}_{2}$ also increased steadily over 6 months in patients with baseline concentration $\leq 15 \mathrm{ng} / \mathrm{ml}$ of $25(\mathrm{OH}) \mathrm{D}_{2}$ who received $50.000 \mathrm{IU}$ of ergocalciferol weekly, but in the subgroup with baseline concentration of $25(\mathrm{OH}) \mathrm{D}_{2}$ between 16-30 ng/ml, levels increased up to 3 months and then decreased between 3 and 6 months, coinciding with the reduction from weekly to monthly dose.

In the studies by Matias et al. (2010), Kumar et al. (2011) and Naini et al. (2015), the dosage of EPO or darbepoetin, the erythroid stimulating agent, was reduced, without modification in hemoglobin levels, with ergocalciferol supplementation. In turn, Nand and Mittal (2017) found a reduction in the dose of EPO and an increase in hemoglobin levels with cholecalciferol supplementation. Agarwal et al. (2016), Miskulin et al. (2016) and Obi et al. (2020) found no significant difference between the groups regarding the dose of EPO, epoetin and darbepoetin, respectively.

According to a study by Matias et al. (2010) and Obi et al. (2020) there was no change in ferritin values, as in the findings of Kumar et al. (2011), participants with a concentration of $25(\mathrm{OH}) \mathrm{D}_{2}<30 \mathrm{ng} / \mathrm{m}$ had higher levels of ferritin during the treatment and follow-up periods of supplementation and transferrin saturation levels were higher in participants with a concentration $\geq 30 \mathrm{ng} / \mathrm{mL}$. In turn, Agarwal et al. (2015) found decreased levels of ferritin and transferrin saturation. Likewise, Nand and Mittal (2017) also found a reduction in ferritin levels.

Vitamin D supplementation culminated in a significant decrease in PTH levels, as reported in Nand and Mittal (2017) and Matias et al. (2010), in Kumar et al. (2011), Porter et al. (2013), Miskulin et al. (2016), Agarwal et al. (2016) and Obi et al. (2020) no significant difference was found in PTH levels.

\section{Discussion}

This review was carried out with a view to investigating the effect of vitamin D supplementation on serum vitamin D concentrations, on anemia markers and on PTH levels in patients with CKD. Regarding the effect of the intervention, most of the studies included in this review found an improvement in the concentration of $25(\mathrm{OH}) \mathrm{D}_{2} 1,25(\mathrm{OH}) 2 \mathrm{D}_{3}$, five studies showed no change in hemoglobin and PTH levels, and four studies showed a reduction in the dose of EPO or erythroid stimulating agent.

\section{5(OH) $\mathrm{D}_{2}$ Concentrations}

In Kumar et al. (2011) few patients reached the goal of $30 \mathrm{ng} / \mathrm{mL}$, attributing this finding to a subgroup of patients who used a central venous catheter, which can confer a greater burden of inflammation, infection or even vascular disease. In the studies by Miskulin et al. (2016) and Porter et al. (2013) there was an oscillation in the concentration of $25(\mathrm{OH}) \mathrm{D}_{2}$. To explain this finding, the authors emphasize the high prevalence of $25(\mathrm{OH}) \mathrm{D}_{2}$ deficiency and insufficiency in their population. Serum $25(\mathrm{OH}) \mathrm{D}_{2}$ concentrations are influenced by many factors, such as: race, skin pigmentation, age, season, latitude, weather conditions, dietary habits and exposure to sunlight. These studies showed a large number of african-american 
participants, decreased consumption of vitamin D foods and decreased exposure to the sun, which justified the need for a second round of ergocalciferol supplementation to normalize $25(\mathrm{OH}) \mathrm{D}_{2}$ concentrations.

The normalization of $25(\mathrm{OH}) \mathrm{D}_{2}$ concentrations can provide a suitable substrate for the local tissue production of $1,25(\mathrm{OH}) 2 \mathrm{D}_{3}$ in hematopoietic tissues via extra-renal activity of the 1- $\alpha$-hydroxylase enzyme. Hematons (the buffy layer of bone marrow containing erythroid precursors, fibroblasts, endothelial cells, lipid loaded cells, and macrophages) have been shown to contain significantly higher concentrations of $25(\mathrm{OH}) \mathrm{D}_{2}$ and $1,25(\mathrm{OH}) 2 \mathrm{D}_{3}$ than do bone marrow plasma. High local concentrations of $1,25(\mathrm{OH}) 2 \mathrm{D}_{3}$ in hematopoietic tissues can then directly activate erythroid precursor cells and thus prevent the development of anemia (Sim et al., 2010; Naini et al., 2015).

Similar to the results of this review, a study by Cuspiti et al. (2015) found an increase in the concentration of $25(\mathrm{OH}) \mathrm{D}_{2}$ with a reduction in deficiency from $76 \%$ to $33 \%$ of patients. Already in Bucharles et al. (2012) found an increase in $25(\mathrm{OH}) \mathrm{D} 2$ concentrations after three months of supplementation, with a concomitant reduction in C-reactive protein and IL-6, suggesting that the correction of hypovitaminosis D has an anti-inflammatory effect.

\section{EPO Dose, Hemoglobin Levels, Ferritin and Transferrin Saturation}

In four studies a significant reduction in the required dose of EPO was found with vitamin D supplementation, attributing this effect to the role of calcitriol as a substrate for bone marrow erythropoietic cells. Studies of bone marrow erythrocyte precursor cells demonstrate that calcitriol increases EPO receptor expression (Patel et al., 2010; Sonkar et al., 2018). Supporting these results, Goicoechea et al. (1998) demonstrated in 28 hemodialysis patients with severe hyperparathyroidism that intravenous calcitriol reduced the need for EPO therapy.

Not all studies found a reduction in the dose of EPO with vitamin D supplementation, this may be related to secondary hyperparathyroidism, infection, production of pro-inflammatory cytokines that stimulate hepcidin synthesis and inhibit the production of EPO in the renal parenchyma. Hepcidin, a small polypeptide that affects iron homeostasis as it reduces the iron available to erythroid precursors and therefore contributes to the development of anemia (López-Ramiro et al., 2017).

The effects of vitamin D supplementation on hemoglobin levels did not show promise in five studies, perhaps because in patients with iron deficiency anemia, vitamin D is unlikely to provide improvements in hemoglobin after correction of iron deficiency. It is worth noting that iron levels were not assessed, which would be important to assess its availability for erythropoiesis and ensure a better understanding of the metabolic behavior of vitamin $\mathrm{D}$ in the pathogenesis of anemia.

Adequate management of anemia for patients with CKD undergoing hemodialysis is a challenge. The ideal hemoglobin targets for balancing EPO-stimulating agents and intravenous iron remain unclear. Giving iron to CKD patients on hemodialysis complements EPO therapy, helps maintain target hemoglobin levels, and reduces EPO dosing requirements. However, the use of iron requires a careful balance between the intended clinical effect and the uncertain risks of toxicity (Kuo et al., 2012; Bailie et al., 2015).

Ferritin is a good indicator of iron stores, but it is an acute phase protein, and its high levels may be related to the underlying disease and its inherent inflammatory process. Transferrin saturation, on the other hand, makes it possible to assess the functionally available iron for erythropoiesis. Of the five studies that evaluated ferritin, three found a reduction in its levels after vitamin D supplementation.

In the study by Kumar et al. (2011), patients with $25(\mathrm{OH}) \mathrm{D}_{2}$ concentrations $<30 \mathrm{ng} / \mathrm{mL}$ had higher levels of ferritin, probably because they are more debilitated patients due to the hemodialysis process that culminates in a large load of inflammation, which contributes to the development of anemia. 


\section{PTH Levels}

It is noteworthy that the inclusion of PTH levels in this study could better clarify the participation of vitamin D in the control of anemia in patients with CKD, given that increased PTH levels can compromise the hematopoietic function and erythropoiesis, suppressing the endogenous synthesis of EPO and, therefore, contribute to the onset of anemia.

Matias et al. (2010) found a significant reduction in PTH levels with supplementation, attributing this effect to the fact that $25(\mathrm{OH}) \mathrm{D}_{2}$ directly activates the vitamin $\mathrm{D}$ receptor in the parathyroid gland independent of $1,25(\mathrm{OH}) 2 \mathrm{D}_{3}$ contributing to the control of hyperparathyroidism secondary. Obi et al. (2020) observed that cholecalciferol suppressed PTH only among patients with very low concentrations of $25(\mathrm{OH}) \mathrm{D}_{2}$.

It is important to consider the role of PTH hypersecretion in renal anemia, which would have direct effects on endogenous EPO synthesis, bone marrow progenitors, and red cell survival. Hyperparathyroidism aggravates hematopoietic function, reduces erythropoiesis, accelerating the rate of erythrocyte sedimentation, and increasing erythrocyte osmotic fragility through Ca-ATPase stimulation (Duque et al., 2020). Vitamin D, due to its beneficial effects in controlling PTH hypersecretion, could improve the anemic condition in renal patients (López-Ramiro et al., 2017).

However, in the present study, such a relationship was not observed, since in five studies no effect of supplementation on PTH levels was reported. Complementarily, Bhan et al. (2015) and Bashardoust et al. (2018) also found that there was no significant difference between PTH levels after vitamin D supplementation. Therefore, it is suggested that the restoration of $25(\mathrm{OH}) \mathrm{D}_{2}$ concentrations and the beneficial effect of vitamin $\mathrm{D}$ on anemia in renal patients may be independent of PTH suppression.

The supplementation time of the studies seems to have been significant for the improvement of the concentration of $25(\mathrm{OH}) \mathrm{D}_{2}$ in most of the studies included in this review. However, in studies with supplementation time greater than 6 months, there was a reduction in the concentration of $25(\mathrm{OH}) \mathrm{D}_{2}$ at the end of the study, coinciding with a reduction in the dose of vitamin D supplementation from weekly to monthly.

It is also worth considering the age of the participants in the studies compiled in this review. In the study by Matias et al. (2011), elderly participants had lower concentrations of $25(\mathrm{OH}) \mathrm{D}_{2}$, and it is already consolidated in the literature that age is related to the concentration of $25(\mathrm{OH}) \mathrm{D}_{2}$ (Sah \& Adhikary, 2019), since this group reduces exposure to the sun as a result of health problems and immobility, also reduces intake of natural sources of vitamin $\mathrm{D}$, and reduces dermal synthesis of vitamin D.

It is noteworthy that this study has some limitations that deserve to be listed. Obtaining a small number of studies that deal with the proposed theme, and which, therefore, made it impossible to deepen the discussion.

In addition, the heterogeneity of the designs included, in terms of the population studied, sample size and duration of the intervention, may have contributed to the collection of controversial data. At this point, in particular, it is emphasized that the ideal would be to elect only randomized clinical trials, as they have high power of evidence, configuring a more reliable method and with less risk of outlier.

\section{Conclusion}

The results showed that the vitamin D supplementation regimen is a well-tolerated and effective strategy to replenish $25(\mathrm{OH}) \mathrm{D}_{2}$ concentrations in the normal range for most hemodialysis patients, however, they reinforce the controversy about the vitamin's behavior. D on the improvement of anemia markers and PTH levels in CKD patients.

In addition, methodological factors such as supplementation dose, season and duration may have contributed to the divergences between the findings. Therefore, the importance of conducting further research with a larger number of articles to 
address issues of dosage and strict controls in the designs for a better understanding of the metabolic behavior of vitamin $\mathrm{D}$ in the pathogenesis of anemia of inflammation is highlighted.

\section{References}

Agarwal, G., Hirachan, P., Gelfond, J., Fanti, P., Hura, C., \& Bansal, S. (2016). Treatment with ergocalciferol does not improve the rate of use and hospitalization of erythropoietin in hemodialysis patients. BMC Nephrology, 17(144).

Agarwal, A. K. (2021). Iron metabolism and management: focus on chronic kidney disease. Kidney International Supplements, 11(1), 46-58.

Al-shaer, O. S., Behiry, E. G., Ahmed, A. A., \& Moustafa, H. (2020). Association between the genetic variant of the vitamin D receptor (FokI) rs2228570 and iron profile in hemodialysis patients. Molecular Biology Reports, 47(1), 545-53.

Arabi, S. M., Ranjbar, G., Bahrami, L. S., Vafa, M., \& Norouzy, A. (2020). The effect of vitamin D supplementation on the concentration of hemoglobin: a systematic review and meta-analysis. Nutrition, $9(11)$

Bacchetta, J., Zaritsky, J. J., Mar, J. L., Chun, R. F., Lisse, T. S., Zavala, K., \& Hewison, M. (2014). Vitamin D Iron Regulatory Hepcidin Suppression. Journal of the American Society of Nephrology, 25(3), 564-72.

Bailie, G. R., Larkina, M., Goodkin, D. A., Li, Y., Pisoni, R. L., Bieber, B., \& Robinson, B. M. (2015). Data from the study of standards of practice and results of dialysis validate an association between high doses of iron intravenous and mortality. Kidney International, 87(1), 162-68.

Bashardoust, B., Zakeri, A., Fouladi, N., Izadi, Z., \& Hosseini, F. (2018). Effect of ergocalciferol treatment on bone metabolism and parathyroid hormone indices in hemodialysis patients. Iranian Journal of Kidney Diseases, 12(6), 359-63.

Begum, S., \& Latunde-Dada, G.O. (2019). Inflammation anemia with emphasis on chronic kidney disease. Nutrients, 11(10), 2424.

Bhan, I., Dobens, D., Tamez, H., Deferio, J. J., Li, Y. C., Warren, S., \& Thadhani, R. (2015). Nutritional supplementation of vitamin D on dialysis: a study randomized. Clinical Journal American Society of Nephrology, 10(4), 611-619.

Bucharles, S., Barberato, S. H., Stinghen, A. E., Gruber, B., Piekala, L., Dambiski, A. C., \& Pecoits-Filho, R. (2012). Impact of cholecalciferol treatment on biomarkers of inflammation and myocardial structure in hemodialys is patient swith out hyperparathyroidism. Journal Renal Nutrtion, $22,584-91$.

Bueno, C. S., \& Frizzo, M. N. (2014). Anemia na doença renal crônica em hospital da região noroeste do estado do Rio Grande do Sul. Brazilian Journal of Nephrology, 36(3), 304-14.

Cuspiti, A., Vigo, V., Baronti, M. E., D’Alessandro, C., Ghiadoni, L., \& Egidi, M. F. (2015). Vitamin D status and cholecalciferol supplementation in patients with chronic kidney disease: an Italian cohort report. International Journal Nephrology Renovascular Disease, 8, $151-157$.

Daimon, M., Fujita, T., Murabayashi, M., Mizushiri, S., Murakami, H., Nishiya, Y., \& Ihara K. (2020). Exacerbation of hyperparathyroidism, secondary to reduced renal function, in individuals with vitamin D deficiency. Frontiers in Medicine, 7, 221.

Duque, S.J., Elias, R.M., \& Moysés, R.M.A. (2020). Parathyroid hormone: an uremic toxin. Toxins (Basel), $12(3), 189$.

Goicoechea, M., Vazquez, M. I., Ruiz, M. A., Gomez-Campdera, F., Perez-Garcia, R., \& Valderrabano, F. (1998). Intravenous calcitriol improves anaemia and reduces the need for erythropoietin in haemodialysis patients. Nephron, 78(1), 23-27.

Kumar, V. A., Kujubu, D. A., Sim, J. J., Rasgon, A. S., \& Yang, O. S. (2011). Vitamin D and recombinant supplementation use of human erythropoietin in vitamins Hemodialysis patients with D deficiency. Journal Nephrology, 24(1), 98-105.

Kuo, K. L., Hung, S. C., Lin, Y. P., Tang, C. F., Lee, T. S., Lin, P. C., \& Tarng, D. C. (2012). Intravenous supplementation of ferric chloride with hexahydrate Induced endothelial dysfunction and increased cardiovascular risk among hemodialysis patients. PLoS One, 7(12)

Lima, M. A. F. (2017). Status de Vitamina D e Fatores Associados em Indivíduos Submetidos a Transplante Renal: Um Estudo Longitudinal (Dissertação de Mestrado). Universidade Federal do Rio Grande do Norte, Natal.

López-Ramiro, E., Rubert, M., González-Parra, E., Mahillo, I., \& De la Piedra, C. (2017). Correlation between 25-hydroxy-vitamin D levels and the degree of anemia in patients with chronic kidney disease. American Journal of Clinical and Experimental Medicine, 5(4), 151-56.

Madu, A. J., \& Ughasoro, M. D. (2017). Chronic disease anemia: an in-depth review. Medical Principles and Practice, $26(1), 1-9$.

Masoud, M. S., Alokail, M. S., Yakout, S. M., Khattak, M. N. K., Alrehaili, M. M., Wani, K., \& Al-Daghri, N. M. (2018). Vitamin D Supplementation Modestly Reduces Serum Indices Arab teenagers ironing. Nutrients, 10(12).

Matias, P. J., Jorge, C., Ferreira, C., Borges, M., Aires, I., Amaral, T., \& Ferreira, A. (2010). Cholecalciferol supplementation in hemodialysis patients: effects on mineral metabolism, inflammation and size parameters cardiac. Clinical Journal American Society of Nephrology, 5(5), 905-911.

Miskulin, D. C., Majchrzak, K., Tighiouart, H., Muther, R. S., Kapoian, T., Johnson, D. D. S., \& Weiner, D. E. (2016). Ergocalciferol supplementation in patients in hemodialysis with vitamin D deficiency: a trial randomized clinical trial. Journal American Society of Nephrology, 27(6), 1801-1810.

Mowbray, P. K., Wilkinson, A., \& Tse, H. H. M. (2014). An integrative review of employee voice: identifying a common conceptualization and research agenda. International Journal of Management Reviews, 17(3). 
Naini, A. E., Hadaiati, Z. P., Gholami, D., Pezeshki, A. H., \& Moinzadeh, F. (2015). The effect of vitamin D administration on the treatment of anemia in patients with terminal renal disease with vitamin D deficiency in hemodialysis: a double-blind, placebo-controlled clinical trial. Journal of Research in Medical Sciences, 20(8), 745-50.

Nand, N., \& Mittal, R. (2017). Evaluation of Effect of Vitamin D Deficiency on Anemia and Erythropoietin Hyporesponsiveness in Patients of Chronic Kidney Disease. Journal of the Association of Physicians of India, 65(2), 38-42.

Neves, P. D. M. M., Sesso, R. C. C., Thomé, F. S., Lugon, J. R., \& Nascimento, M. M. (2021) Inquérito brasileiro de diálise 2019. Brazilian Journal of Nephrology, 43(1).

Obi, Y., Yamaguchi, S., Hamano, T., Sakaguchi, Y., Shimomura, A., Namba-Hamano, T., \& Isaka, Y. (2020). Effect of cholecalciferol on serum hepcidin and parameters of anaemia and CKD-MBD among haemodialysis patients: a randomized clinical trial. Scientific Reports, 10(1), 15500.

Oliveira, W. V. J., Zica, C. L. A., Gouveia, I. P. P., Vasconcelos, M. O., Oliveira, R. R., \& Oliveira, T. S. (2019). Anemia de doença crônica na doença renal crônica. Revista Conexão Ci, 14(2), 57-65.

Patel, N. M., Gutiérrez, O. M., Andress, D. L., Coyne, D. W., Levin, A., \& Wolf, M. (2010). Vitamin D deficiency and anemia in chronic kidney disease precocious. Kidney International, 77(8), 715-720.

Porter, A., Gilmartin, C., Srisakul, U., Arruda, J., \& Akkina, S. (2013). Prevalence of vitamin D 25-OH deficiency in a population of hemodialysis patients and the effectiveness of a supplementation regimen oral ergocalciferol. American Journal Nephrology, 37(6), 568-574.

Riccio, E., Sabbatini, M., Bruzzese, D., Capuano, I., Migliaccio, S., Andreucci, M., \& Pisani, A. (2015). Effect of Paricalcitol vs Calcitriol on hemoglobin levels in patients with chronic kidney disease: a randomized study. Plos One, 10(3).

Sah, S. K., \& Adhikary, L. P. (2019). Prevalence of abnormal serum 25-hydroxyvitamin D and its association with hemoglobin level in patients with predialysis CKD: one cross-sectional study of the Himalayan country. BMC Nephrology, 20(267).

Sim, J. J., Lac, P. T., Liu, E. A., Meguerditchian, S. O., Kumar, V. A., Kujubu, D. A., \& Rasgon, S. A. (2010). Vitamin D deficiency and anemia: a crosssectional study. Annals of Hematology, 89(5), 447-52.

Smith, E. M., \& Tangpricha, V. (2015). Vitamin D and Anemia: Insights into an Emerging Association. Current Opinion in Endocrinology, Diabetes and Obesity, 22(6), 432-38.

Sonkar, S. K., Singh, H. P., Sonkar, G. K., \& Pandey, S. (2018). Association of vitamin D and secondary hyperparathyroidism with anemia in diabetic kidney disease. Journal Family Medicine Primary Care, 7(4), 815-818.

Zughaier, S. M., Alvarez, J. A., Sloan, J. H., Konrad, R. J., \& Tangpricha, V. (2014). The role of vitamin D in regulating their on-hepcidin-ferroportinax is in monocytes. Journal of Clinical and Translational Endocrinology, 1(1). 